Volume II - Article 1

\title{
Essay: The Future of Law Reviews and Legal Journals From a Student Editor's Perspective
}

\author{
Bradley J. Martineau
}

Fall 2001

\section{Copyright (C) 2001 University of Pittsburgh School of Law Journal of Technology Law and Policy}

\begin{abstract}
Introduction
Law reviews and legal journals have been part of the legal academic world for more than a century. [1] These legal publications are unique because they are completely run by students. However, over the last few decades, law reviews and legal journals have been highly criticized, and some critics even predict their demise. [2] If law reviews and legal journals expect to survive and remain valuable academic resources, then certain changes need to be made, and these changes are the responsibility of the student editors. Although some legal publications are making changes for the better, such as publishing online, more can be done to improve these student-run publications. By taking advantage of technological advances, especially the Internet, law reviews and legal journals can reduce the time it takes to publish an issue. In addition, these technological advances allow legal publications to offer many new features and services for both the authors and the readers. However, updating a publication with these new technological advances can be expensive. Thus, law reviews and legal journals need to generate more income from other sources than just subscriptions.
\end{abstract}

Law reviews and legal journals must also make basic changes to the way articles are selected and the manner in which the authors' articles are edited. First, the articles selected for publication should be based on a "blind" selection process. [3] Second, student editors should be more deferential to the authors. Many authors have different styles of writing, and as long as the author's style is grammatically correct, student editors should defer to the author. However, student editors should still edit the author's article and make stylistic suggestions [4], but the ultimate decision whether to implement these recommended changes should be the author's. Thus, student editors should take the perspective that they are providing an editing service to author rather than telling the authors how they must write their articles before they will be published.

Part I of this essay examines how law reviews and legal journals have traditionally operated, and the relevant criticisms regarding these traditional publications. Part II of this essay discusses the future of law reviews and legal journals and how they need to change so that they can continue to be a useful academic resource for students, professors, judges, and practitioners. 


\section{Traditional Law Reviews and Law Journals}

Although the traditional law reviews and legal journals have been highly criticized, these student-run publications provide a valuable service to authors in several ways. First, the law reviews and legal journals give faculty a visible forum to publish. [5] Second, students help to research, locate, edit complex footnotes, and verify sources for the authors. [6] Third, students provide editing advice to the authors, and they ensure the article's authenticity and proper format when it is published. During the students' edits, the authors are also permitted to make any last minute changes to their articles, and the students incorporate these changes for the authors. [7]

Most notably, law reviews and legal journals have been used as a screening device for good legal scholarship. Professors especially depend on getting published because it is an important factor in becoming tenured. Law reviews and legal journals are one of the only respectable forums available to faculty so that they may become published. However, as not every article gets published, law reviews and legal journals operate as a "sifting" device. Finally, law reviews and legal journals provide valuable resources, such as a cheap editorial staff and otherwise expensive equipment (computers, software, copiers, printers, etc.). [8] These publications also pay the cost of printing the authors' articles. Ultimately, law reviews and legal journals provide valuable services to the authors.

\section{A. The Production Process}

\section{Selecting the Articles}

The production process for traditional law journals is fairly uniform. Potential authors - practitioners, professors, and students - submit their manuscripts by mail, usually a hard copy of the article and a copy saved on disk. [9] The student editors responsible for selecting the articles weed through numerous manuscripts, consisting of thousands of pages, to determine which authors will receive offers of publication. [10] Once these editors select the articles that the journal would like to publish, the authors are then notified and are given a deadline to decide whether to accept publication with the journal. [11] The selected authors, on the other hand, then contact all of the journals that they submitted their manuscripts to and let those journals know that they have an offer for publication. The authors ask the journals in which they would like to see their article published for an "expedited review," so that they can decide which offer for publication they will accept.

\section{The Book Pull}

Once an author accepts a publication offer from a journal, the traditionally slow publication process begins. First, the publications convert the author's article into the format that it uses to edit the articles. [12] After the article is in the proper format, the publication begins a series of edits, which are performed by the student editors. [13] Before the edits can begin, the student editors must locate all of the sources cited in the author's footnotes and physically place the source on the shelves of the journal's offices so that the editors can reference the footnotes against the sources. This process of pulling the cited books and placing them on the shelves is commonly known as the "book pull." As some of the cited sources cannot be found at a local library near the law school, the 
journal will sometime request that the author send the source or copies of the cited pages from the source.

One of the problems with the book pull is that locating all of the sources is very time consuming. Moreover, the publications tend to incur numerous late fees because the books will sit on the shelves for months. Another problem is that the publications usually operate in cramped quarters, having hundreds of books on the shelves and tables taking up a lot of space. Lastly, law librarians generally do not like the fact that the student editors keep case books, statutes, law reviews, journals, treatises and other law related books on their shelves for such extended periods of time. Since these sources are not checked out of the library, law librarians do not have any way of knowing where they are. Even if law librarians know that the publication has these sources, the sources are not easy to find because they are generally shelved according to author and not by the indexing system that the library uses. Thus, this can hinder the research of patrons of law libraries because they might not be able to find the sources they are looking for as they are in the law review or legal journal's office and not on the library's shelves.

\section{The Editing Process}

Once all of the cited sources are on the publication's shelves, then the students begin editing. First, student editors are assigned to an author's article. [14] Each student's edit can take anywhere from two to three weeks, depending on the length of the author's article. [15] Generally, there are three or four stages of student edits as the author's article progresses up the chain of command within the publication. [16] Once the student editor completes his or her edit, the student will make a copy of the edits and mail the author a copy so the author can see what has been changed. [17] These edits are usually mailed to the author by overnight or priority mail, which can be expensive.

The author then decides whether or not to incorporate the student's edits. In addition, the author will also usually make other revisions to his or her article and request that these changes be incorporated. Once the author reviews the student's edits and makes any additional changes to the article, the author mails the article back to the student editor. The editor then incorporates the approved changes into what is commonly called a "clean copy." However, sometimes the student editors make changes to the author's article when the author has specifically asked that the student not to make the suggested changes. Nevertheless, this clean copy passes onto to the next student editor assigned to the author. From start to finish, it is easy to see why one stage of edits can take several weeks if not more than a month.

Once the next student editor receives the clean copy, he or she begins his or her edit. The process starts all over again, and continues until the last student editor, usually the editor-in-chief, completes his or her edits. The most time consuming and most expensive part of this process is mailing the edits back and forth between the authors and the students. [18] During the whole editing process, the edits will generally spend anywhere from one to two weeks in the mail between the student editors and the author.

\section{The Publisher}


After the final student edit is completed and approved by the authors, then the authors' articles are sent by mail to the publisher. The publisher then converts the articles into its system. This process can take anywhere from four to ten business days, depending on the publisher. Once the publisher converts the articles, the publisher will set the articles into "book pages". The publisher then mails the articles back to the publication so the student editors can ensure that the articles are in the proper format and the changes are properly incorporated.

If any changes need to be made at this time, or if the publisher did not format an article properly, the student editors make the changes and mail the corrected book pages back to the publisher. The publisher then incorporates the changes and mails back the revised book pages. This process continues until the publication is satisfied with the final result. This final step of the process can take anywhere from a few weeks to months, depending on how quickly the publisher responds to the changes.

\section{B. The Economics - Revenues vs. Costs}

Clearly, this back-and-forth process of mailing the massive transcripts is timely and expensive for law reviews and legal journals, especially considering a typical publication will publish four or more articles each year. Under this traditional process, a publication is lucky to publish an issue from start to finish in four to five months, assuming no unexpected delays arise in the meantime such as problems communicating with an author. The final product of this timely and expensive process is the journal in book format. To cover the costs of publishing in book format, most publications charge anywhere from $\$ 20$ to $\$ 45$ for a yearly subscription. Depending on the number of subscribers, the revenue that is generated from subscribers will be unlikely to cover the expensive costs of publishing the issues in book format.

For example, assume the average law publication has 1000 paying subscribers, and that the publication charges $\$ 30$ per year for a subscription of four issues. The average cost of the traditional process described above, including postage, can cost a journal anywhere from $\$ 7,000$ to $\$ 12,000$ per issue. This cost can fluctuate depending on how many additional changes a law review or legal journal requires the publisher to make once the publisher has set an issue into book pages. Postage alone can cost a journal anywhere from $\$ 1,000$ to $\$ 2,000$ per issue. However, these costs also do not factor in the costs of the computers, software, printers, printer cartridges, paper, phone charges, and office supplies that the publication incurs during this production process. On average, it can cost a publication another $\$ 2,000$ to $\$ 5,000$ per year for these additional costs. Overall, a publication's total cost of production for publishing four issues per year is approximately $\$ 45,000$ per year.

If the publication collects all of the subscribers' dues, it can generate about $\$ 30,000$ per year in revenue. The average publication also probably generates anywhere from $\$ 5,000$ to $\$ 10,000$ in royalties from LEXIS and Westlaw. [19] Thus, if a publication is able to collect these revenues, it can ideally expect $\$ 40,000$ a year in revenue. Ultimately, the traditional publications’ production process is expensive, and generally a losing business proposition for law schools. Nevertheless, law schools justify 
supplementing law reviews and legal journals financially because of the prestige that they bring to the schools. [20]

\section{Criticisms}

Many of the criticisms of the traditional journals stems from this timely and expensive production process. First, critics argue that traditional law reviews and legal journals take too long to publish articles. [21] Many articles are time sensitive issues, and the six months or more it takes to publish the article may render them moot and, understandably, authors become extremely frustrated with the publication. Second, since law students run law reviews and legal journals, critics argue that students are incapable of selecting good scholarship because they are inexperienced. [22] Third, the critics contend that it is inappropriate for students to edit and tell professors and practitioners how to write their articles. [23]

Another problem with the traditional law reviews and legal journals is that only a very limited audience is able to read the journals. [24] Typically, most of the subscribers of these journals are the libraries and former alumni. Thus, the potential audience is very limited. However, ever since Westlaw and LEXIS started publishing most of the journals on line, the audience has been extended to include a large number of practitioners, professors and students that did not have prior access to the journals. Nevertheless, the potential reading audience remains limited when the journals are published in the book format.

Some critics thus argue that the next decade could witness the end of the law reviews and legal journals, as we know it, due to technological advances and the Internet. [25] Professor Bernard J. Hibbitts from the University of Pittsburgh School of Law states that professors and practitioners will start to "self-publish" their articles on the World Wide Web. [26] He states that the Web allows authors to publish their articles much more quickly and with more flexibility. [27] First, it permits the author to create colorful graphs, pictures, or other designs to be included in the article, instead of the stagnant black and white format that the articles have been limited to for the past century or more. [28]

Second, Hibbitts contends that the Web allows the author to include hypertext links within his or her article. [29] Instead of the article being inundated with footnotes, the reader will just click on the hypertext link and go right to the source of the information being cited. [30] Hypertext links would also permit the author to include additional information for the reader. [31] Hibbitts also argues that if authors selfpublish, this will eliminate the frustrations caused by student editors who attempt to edit and substantively change the author's article. [32] Thus, he states that authors can create their own web pages, publish their articles on it, and these web pages could even contain message boards on them so that the readers can react and interact with each other about the article. [33]

Hibbitts also suggests that an email link could be included on the author's web page so that readers can give the author direct feedback. [34] In addition, he emphasizes 
that publishing on the Web is very cost effective. [35] In fact, Hibbitts stresses that it really does not cost anything except for the cost of the web page, which is minimal. [36] Lastly, Hibbitts believes that the web allows an author's article to be updated as the author's views change or as the relevant area of law changes. [37] For example, an author may publish an article in October 2001 on the Web about a federal income tax issue. However, in May 2003, the law may have been amended and the author could have a different perspective on the issue. As the author published his or her article on the Web, the article can be updated and a new version of the article can be posted to the web page. Thus, the author could have multiple versions (version 1.0 and 1.1) of this article on his or her web page.

One of the shortcomings Hibbitts foresees with self-publishing is the ability of readers to locate articles. [38] Hibbitts had articulated a central database solution that stores all of the articles in some sort of indexed and orderly fashion. [39] This central database would allow someone to search for an article by keyword, title, or author. [40] Alternatively, a viewer could locate the article through an index. [41] However, Hibbitts acknowledges that either one of these central database solutions requires at least one systems administrator to maintain the database, which could be costly. [42] Nonetheless, the owner of such a database could generate enough revenue from advertising to cover any costs and then some. As an alternative to the central database solution, Hibbitts suggests that a system similar to Napster [43] be set-up where all of the articles can be shared with one another through an article-sharing network. [44]

\section{The Future of Law Reviews and Legal Journals}

The future holds a very different look for the law reviews and legal journals in several ways. First, in order for law reviews and legal journals to remain competitive and useful, they need to streamline their production process so that they are published on-time and much quicker then they have been in the years past. Second, law reviews and legal journals need to publish their full-text articles on the Internet so that the publications reach a wider audience. By publishing on-line, this will also save law reviews and the legal journals money on the production costs. Not only do these publications need to publish on-line, but law reviews and legal journals also need to utilize all of the technological capabilities that the Internet has to offer, such as color graphs, pictures, message boards, video clips, and tele-conferencing. Third, law reviews and legal journals need to advertise, get sponsors, and hold annual banquets as a way to generate revenues. Fourth, law reviews and legal journals as a whole need to defer to the wishes of academic authors as to the substance and style of their articles. Finally, legal publications should remove the names of the authors from the manuscripts when they are submitted to the journals to be selected. If law reviews and legal journals make these changes, they will continue to serve as valuable academic resources for many years to come.

\section{A. The Production Process}

\section{Selecting the Articles}

Although many critics believe that students are not experienced enough or competent enough to select which academic articles will be published, this is just not the case. First, the students selecting the articles are not inexperienced. Rather, they are 
third year law students who have been exposed to many different legal subjects. [45] Moreover, these students are generally the top students in their class. Consequently, they are very good legal writers and researchers, and are thus able to discern the difference between a well-written article and a poorly written article.

Second, it does not take a legal "expert" to be able to tell if an article is interesting or if it is a novel issue in the law. [46] Who is to say that a practitioner or a professor is more capable of deciding if an article is well written and if the article addresses a novel issue of the law? Most practitioners and professors specialize in only one or two areas of the law. Thus, they might be more experienced in selecting articles in their areas, but there is no reason why they are more capable of selecting articles that do not deal with their area of specialty. In particular, law reviews publish articles on any topic of the law as long as that article raises novel issues in that area of the law it addresses. Students are in the best position to decide which articles get selected because they are generalists in the true sense. As third year law students, they are being exposed to many different legal subjects and these legal issues are fresh in their minds. Therefore, students selecting articles for publication are experienced and do know enough about the law to make educated decisions as to their selections.

Finally, the current selection process serves one last important function, and this function gives validity to the articles that get published. If any author is able to "selfpublish" on the Web, then there will not be an unbiased intermediary who screens the articles to make sure they are well written and raise novel issues in the law. Without an unbiased intermediary, anyone could publish anything, no matter how trivial and poorly written the article may be. Law reviews and legal journals serve a valuable function in the academic legal community by selecting which professors will be published. As a professor, getting published is a very important factor if he or she wants to become tenured. [47] If every professor is able to "self-publish" on the Web, then how will the tenure committees be able to differentiate between professors? Will the tenure committees rely solely on peer review?

One may argue that a rating scheme could be imposed on the self-published articles, but this could be very complicated and expensive. [48] Another argument for validating the self-published articles is by the number of "hits" that the web page receives. [49] However, the number of hits a web page receives does not necessarily mean that the self-published article is very well written or that it raises novel issues in the law. Ultimately, something or someone needs to serve as a "screen" or validating mechanism so that the good articles can be weeded out from the poorly written or repetitive articles.

Conveniently, third year law students are the best solution for this problem. Students can offer their services for free. If law reviews or legal journals were published as a commercial publication by professors or practitioners, it would cost the publication a significant amount of money to pay the editors. [50] Moreover, practitioners and professors generally do not have the time to devote to publishing a journal multiple times year after year. [51] Publishing a law review or legal journal is a full-time job. Thus, 
third year law students are in the best position to do this because their services are free and they have the time to devote to the publication. Furthermore, the students only have to devote their time and services to the law review or legal journal for a year or two before incoming second and third year law students replace them. This quick turnover guarantees an endless supply of talented and devoted free labor.

Nevertheless, one major change does need to occur in law reviews and legal journals, and that is the selection of the articles should be "blind." [52] In other words, someone on the editorial staff should remove the authors' names and the institutions that they work for from the article before the articles are considered for publication. This ensures that the best legal articles are selected and published.

Ultimately, the current system in place for selecting the articles, along with removing the names of the authors and their affiliations, is the best system available.

\section{The Book Pull}

It has been the traditional practice to pull every book off the shelves of the library so that the editors can conveniently have them on hand to check the author's cites in his or her footnotes. [53] However, with Westlaw and LEXIS gaining popularity and becoming more reliable every day, pulling books off the libraries shelves must change to a certain extent. All cases, statutes, law reviews, codes, ALR's, some treatises, and even some magazines can be obtained on-line from either Westlaw or LEXIS, and from many public web pages. Thus, it is not necessary to pull these sources off the shelves any longer because both Westlaw and LEXIS give the student members of law reviews and legal journals unlimited access to sources, and they even provide printers and paper.

Not only does eliminating this part of the book pull save time, but it also saves space, which is especially important as law reviews and legal journals are generally working in cramped offices. Leaving these books on the shelves in the library also makes librarians happier because these resources remain readily available to the public, who may not have access to Westlaw or LEXIS. Another advantage of using these electronic resources is that it permits a student editor to check cites that contain sources found on Westlaw or LEXIS from anywhere as long as he or she has access to the Internet. Westlaw and LEXIS also enable a student to do a full text search for direct quotes or key words within a source. As for the authors, most of them are law professors and they are also given unlimited access to Westlaw and LEXIS. Consequently, chances are these professors used Westlaw or Lexis when they cited cases, statutes, codes, legislative history, law reviews, and other resources in their articles. Overall, utilizing the technology that is provided to law reviews and legal journals for free will save time and space during the production process.

\section{The Editing}

Technological advances have also made it possible to shorten the editing process, which has historically been criticized as being slow and drawn out. [54] Computers are now able to store large documents, such as long articles. Student editors are now also able to make their edits directly on the computerized version of the article. Word 
processing programs such as WordPerfect and Microsoft Word allow a user to make "redline" changes. By redlining the text or footnotes that have been changed or added, the edits are much more clear and legible for the author to read. Again, the student editor can complete his or her edits anywhere he or she has access to a computer. Once the student editor has completed the edits, then he or she can just email the article as an attachment to the author.

There are several obvious advantages to e-mailing the articles instead of sending the edited article by overnight or priority mail. First, e-mail does not cost the law review or legal journal anything. As mentioned above, a traditional journal can spend anywhere from $\$ 1,000$ to $\$ 2,000$ per issue on postage costs. Second, the author receives the article immediately. Even when the articles are mailed overnight or by priority mail, it still takes a day or two before the author receives his or her edited article. In turn, once the author has reviewed the edits and made any additional changes, he or she can then e-mail the article back to the student editor. Again, this will save the authors money and it will save law reviews and legal journals time during the production process. In short, law reviews and legal journals will eliminate two to three weeks from their production schedule just by sending the articles by e-mail.

Another change that law reviews and legal journals need to make in order to survive in the future is to defer to the wishes of the academic authors. One of the major criticisms of law reviews and legal journals has been that the student editors make too many substantive and stylistic changes to the author's article. [55] Although student editors should be deferential, the student editors should still make suggested changes to the style, wording and substance of an article. However, the author should have the last say as to whether he or she wants to incorporate the suggested changes. Student editors should insist on changes to the article if there is something that is blatantly wrong, such as spelling or if a footnote is not in proper Bluebook form. If law reviews and legal journals take this deferential approach, fewer professors and practitioners will be so critical of these publications. Although some law reviews and legal journals have formally taken this approach, more law reviews and legal journals need to adopt this philosophy.

Law reviews and legal journals need to embrace technology, and take advantage of the computer software that is available to them. Before, law reviews and legal journals sent the completed edits to the publisher, which in turn converted the articles into book pages. This process usually took seven to ten business days. Moreover, when the publisher converts the articles into book pages, often there are mistakes caused by this conversion. Instead of sending the edited manuscripts to the publisher as law reviews and the legal journals have done in the past, there is now computer software that enables publications to format the articles into book pages themselves. This too cuts another few weeks from the production schedule.

Furthermore, if law reviews and legal journals use the same software throughout the editing process and convert the articles into book pages themselves, this will also eliminate the additional errors that can be caused by the conversion between software 
programs when the publisher performs this task. Most publishers will provide the law reviews and legal journals with this software ("macros") at no charge. In addition to providing the software, publishers charge a lower fee per page to print the issues because now the majority of the "typesetting" is in the hands of the law reviews and the legal journals, not the publisher. The publisher can create the table of contents, set the cover for the issue, and set the printer plates with the final book page images. Once this is completed, the only thing left to do is to print and ship the issues, although this part of the process might also change dramatically in the future.

\section{The Publisher}

In the not so far future, all law reviews and legal journals will be publishing their journals on the Internet. Today, many law reviews and legal journals are publishing on the Web; however, most of these publications are just reprinting the black and white words as they appear in the book format onto the Internet. These legal publications are not utilizing the new technology that the Internet has to offer. Nevertheless, this is a major improvement over the traditional book format for several reasons.

First, the Internet enables the publications to reach a wider, while at the same time a more targeted audience as compared to the book format. [56] Instead of being limited to the libraries and the subscribers, now law reviews and legal journals can be easily accessed by anyone from anywhere as long as the person has a computer with Internet access. Moreover, people can access the articles for free. Before, a person could only read the articles on a regular basis from a law review or legal journal if they were a subscriber of if they had access to a public law library. Now, these articles can be accessed by anyone, including non-subscribers, from anywhere in the world. The key quality measure of a law review or legal journal is how many times the publication gets cited. If the publication's articles are available on the Internet for free, this will increase the chances that someone will cite to or rely on an article.

Second, the Internet is a much cheaper medium to publish articles than the traditional book-format. [57] As demonstrated by the hypothetical cost analysis above, most law reviews and legal journals tend to lose money on a yearly basis. Consequently, it is costing these publications and the law schools more money to publish than they are bringing in from subscriber revenues. If these publications begin to publish their articles on the Internet and provide them to the public for free, then their number of subscribers will drop until they only have to publish a couple hundred books per issue. [58] As a result of cutting the issues printed in book format down to a couple of hundred issues, the printing costs will be reduced to approximately $\$ 7,000$ to $\$ 10,000$ per year as compared to before when it can cost an average legal journal anywhere from $\$ 35,000$ to $\$ 40,000$ per year. Furthermore, it will not cost anything to print the articles on the Internet, except for the time and labor it takes to edit them and place them on the Web. Student editors can do both of these duties cheaply.

The third advantage to publishing the articles on the Internet is that law reviews and legal journals can take advantage of all the technological advances that the Internet has to offer. [59] As Professor Hibbitts suggests about "self-publishing," law reviews 
and legal journals can now have message boards on their web sites and make the journal more interactive. Readers of the articles would then be able to post comments about the article's topic, or give constructive feedback. Moreover, readers would be able to interact with each other about the legal topics discussed in the articles. However, the publications would monitor and screen the messages that get posted on the boards. If the authors of the articles wanted to respond to comments on the message boards, they too would be able to post messages.

Another feature that law reviews and legal journals can take advantage of by publishing on the Internet is color. Law reviews and legal journals have always been printed in black and white. In addition to printing in black and white, graphs, charts and pictures have always been in black and white. The main reason that the publications have always printed in black and white is because it is too expensive to print the books in color. However, "printing” on the Internet does not cost anything. This is not to say that law reviews and legal journals should print their text in color. Instead, this gives the publications the capabilities of printing graphs, charts, and even pictures in color. Moreover, the publications can even include a video clip of the author giving additional comments about his or her article, or video clips on relevant legal or societal issues contained in the article. Law reviews and journals can even incorporate videos within the articles if it is appropriate (e.g. oral arguments or a clips from a trial). The economic barriers that existed before are not so limiting now, and thus the publications can be more creative.

A fourth advantage of using the Internet and creating a web-page for law reviews and legal journals is that these publications can now hold e-mail symposiums or even live symposiums on a message board. In fact, law reviews and legal journals could even teleconference symposiums with web-cams. This would enable all members taking part in the symposium to participate without having to travel. Because it would be less inconvenient for the symposium members, this would likely increase participation. Law reviews and legal journals could then broadcast the symposium live on its web page, allowing anyone to view the symposium. The symposium can also be recorded and saved on the web page for later viewing.

Another advantage of the Internet is that fact that the articles can contain hypertext links to a source containing additional information. For example, all of the footnotes of the articles can be hypertext links to either Westlaw or Lexis, assuming Westlaw or LEXIS has the cited source in its database. An author would also be able to have hypertext links contained in his or her article that would connect the reader to other web sites. If an author, for example, were to discuss the Department of Justice, then the author could have a direct link to the Department of JusticeÕs web-site so the reader could obtain more information about the subject if the reader so desired. Hypertext links allow an author to provide endless amounts of information to the reader. Instead of just referring to the fact that additional information is available on a subject in a footnote, the author can now provide a direct link for the readers, and inevitably will save the reader the time and inconvenience of having to look this information up. 
By publishing their articles on the Internet, law reviews and legal journals can have the authors update their articles from time to time by creating versions of the original article. [60] Because law reviews and legal journals rely so heavily on being cited, this will allow the articles to remain a viable and current source of information; thus increasing the odds that the law review or legal journal will be cited in the future. This also allows the author to add or change substantive analysis to his or her article if the law changes or if the author's viewpoints on the subject change. Although a new version of the article would be created and posted to the publication's website, the original article could also remain posted on the web site so that the two articles can be compared or so that the original article can be referenced. Hibbitts suggests that a numbering system such as version 1.0 and version 1.1 be used to identify the articles. [61] Therefore, the articles can be differentiated and cited to appropriately when referred to by another source.

One minor change that law reviews and legal journals will have to make when publishing on the Internet is to number the paragraphs of the articles. If a law review or legal journal is publishing both in book format and on the Internet, the page numbers of the articles might be different unless the publication posts the articles in PDF format and not HTML format. If the article is posted on the Web in PDF format, this will usually be an exact replica of what the articles look like in the book format. However, if the publication is using PDF format, then it will not be able to take advantage of hypertext links and video clips. Moreover, it is not as easy to do a text search in PDF format as it is in HTML format. In PDF format, the publication must enter in keywords that describe the article so that when a search is performed, the article can be found. On the other hand, if the publication uses HTML format, then a person can do a search, which will search the entire article for a keyword.

If the publication is using HTML format, then the editors are going to have to manually enter the page breaks into the articles so that they coincide with the pages in the book format. However, if the publication is only publishing on the web and does not publish its articles in book format, then the publication will not have to worry about making sure the page numbers are the same. Another alternative to manually entering the page breaks is to eliminate the current numbering system all together. Instead of numbering the pages, law reviews and legal journals would number the paragraphs (e.g. ,1, ,2, etc.).

Some legal journals have already adopted this approach, however they are using it in conjunction with the page numbering system. [62] Some librarians believe that the paragraphing numbering system will eventually replace page numbers because resources are being published simultaneously in book format and on the Internet. [63] Nevertheless, if publications use the paragraph number system instead of page numbers, then publications can publish in book format and on the Internet without having to keep the format of the article the same on the Internet as it is in the book format.

The Internet has many more options to offer law reviews and legal journals than the traditional book format. Not only does the Internet provide more options, but 
publications can also publish their articles a lot faster as compared to publishing the articles in the book format. [64] By publishing directly on the publication's web site, publications eliminate the whole process of sending the articles to the printer, unless they continue to print a couple of hundred issues. Consequently, this can eliminate weeks, if not months, from the production schedule.

Ultimately, if law reviews and legal journals utilize these options, then they will be able to remain viable academic resources. Moreover, these publications will also be able to overcome many of the criticisms that have been haunting them for the past several decades.

\section{B. The Economics; Revenues vs. Costs}

On its face, it appears that offering the law reviews or legal journals free of charge on the Internet may be a problem because this will decrease the revenues that are generated in the form of subscriptions. However, most law reviews and legal journals operate at a loss. [65] Thus, by publishing online and offering the articles for free, the publications will cut the number of books that they need to print, and consequently this will cut the costs of publishing.

Assume we have a publication that is an average journal like the one we discussed in Part IIB. If the publication cuts the number of issues that it prints in book format from 1000 per issue down to 200 per issue, then the printing costs for the year will be cut drastically. As mentioned earlier, the estimated cost of printing 1000 issues in book format is approximately $\$ 40,000$ per year. If the publication is only printing 200 issues in book format, then the cost of printing will range from $\$ 7,000$ to $\$ 10,000$ per year. Moreover, it will not cost the publication anything to publish its articles on the Internet, except for the time it takes to post them on the web site or if the publication must hire a webmaster. Most likely, however, the law school will already have a full-time webmaster on staff whose services will be available to the publications.

Consequently, the average law review or legal journal will incur about $\$ 10,000$ per year in printing costs. If this average publication also stops mailing the student edits back and forth between the authors and the student editors, then the publication will also save a lot of money each issue that it would have otherwise spent on postage. Most publications, however, are still going to have basic costs for supplies, new computers, printer cartridges, long distance bills (this to can be minimized by using e-mail), and some minor postage costs. Nevertheless, the average publication that does not spend its money foolishly can minimize these costs to about $\$ 2,000$ to $\$ 3,000$ per year. Thus, the total costs an average law review or legal journal can expect to spend are about $\$ 12,000$ to $\$ 13,000$ per year.

The real question becomes where the revenues will come from if law reviews and legal journals cut subscriptions. The answer is simple - the revenues will come from different sources. First, the average publication, as discussed earlier, will still have about 200 subscribers. Because the publication now wants to discourage subscribers ordering its publication in the book format, the publication can raise its subscription price to at 
least \$40 per year. [66] This will further discourage subscriptions and encourage people to view the articles on the publicationÕs web site for free. However, in the meantime, those subscribers that do want the publication in the book format will pay a fair value for the publication in relation to what it costs to print and distribute the issues. Law reviews and legal journals should also raise the prince for a single order of an issue and charge the person buying the issue the cost of shipping. Therefore, the average publication can generate at least $\$ 8,000$ per year. [67]

The second source of income for the average law review and legal journal is the royalties that the publication receives from LEXIS and Westlaw every year. Again, these royalties can range from $\$ 5,000$ to $\$ 10,000$ per year for the average publication, depending on how often the publication is used on these legal databases. Keep in mind, however, that as law reviews and legal journals begin to publish their full-text articles on the Internet for free, practitioners, students, and professors will be less likely to use LEXIS or Westlaw to access an article. Consequently, these royalties will probably decrease. Nevertheless, a publication can conservatively expect to receive $\$ 3,000$ to $\$ 5,000$ a year from Westlaw, LEXIS, and any other electronic legal databases that form in the future.

A third source of revenue available to law reviews and legal journals is advertising. Some law reviews have already begun to advertise in their issues. [68] Advertising is a valuable tool that can generate substantial revenues for an average size publication.

A publication can offer advertisements in two forms. First, law reviews and legal journals can sell advertisements in the book format. The publication can sell advertising space on the inside front cover, the back cover, the back inside cover, and sell advertising space in a section in the front of the issue designated "Advertisements." Obviously, the premium advertisement spaces are the inside front cover, the back cover and the back outside cover. These "premium" advertisement spaces should be the easiest ones to market. The publications can sell this space at higher prices. In addition to selling individual advertisements, the publications can try to entice companies into signing a year contract at a $5 \%$ to $10 \%$ discount. If the publication can sell the advertisements in annual contracts, then the publication will spend less time on solicitation.

The advertisements can be either full-page or half-page, and they should be priced accordingly. The more popular the legal publication, the more money the publication can charge for advertising in its publication. However, an average law review or legal journal can expect to charge \$200 to \$300 per full-page advertisement in the section designated to advertisements. The first advertisement in this section will be more valuable then the last advertisement because it is the first one a reader would see. Thus, the publication can charge more for the first advertisement and each successive advertisement will cost a little less. Law reviews and legal journals can attempt to fill an advertisement section with 20 to 25 ads, which would only take up 10 to 12 actual pages in the publication. Although readers may be turned off by the advertisements, they can be contained to one small section, unlike a typical commercial magazine. 
When advertising, law reviews and legal journals will want to target legal companies to advertise in their publications. Some examples are Westlaw, LEXIS, Barbri or other Bar Review courses, law book publishing companies, law firms, nonprofit firms, accounting firms, symposiums, libraries, and the list goes on. If an average law review or legal journal can obtain 10 advertisements per issue (4 issues per year) at an average of $\$ 225$ per ad, then the publication can generate another $\$ 9,000$ per year in revenue. All of a sudden, a publication that used to cost the law school thousands of dollars each year to run is now generating money each year and supporting itself.

One may wonder why anyone would want to advertise in law reviews or legal journals if it is only now printing 200 issues per year? The answer is simple for several reasons. First, the law review is still printing 200 issues, many of which will go to libraries where they will be available to view by the public all around the nation or even the world, for many years. Second, the law review or legal journal might be printing more than 200 issues per year, and thus it will be more attractive to potential advertisers. Third, the law review or legal journal can place these advertisements on their web page along with the articles, assuming the university or college permits this. Thus, the potential viewing audience of the advertisements is limitless.

If the publication is having a hard time selling advertisements in the book format, then the publication should concentrate on selling advertisements for the web page. A counter can be placed on the web page and this will give the potential advertisers an idea of how many people view the web page every day. The more "hits" the web page is able to receive, the more likely the publication will be able to sell advertisements. When law reviews or legal journals are selling the advertisements for the web page, they can offer to "throw-in" a free ad in the book format, and thus the advertising package will be that much more attractive. Again, before publications begin advertising in either the books or on the web site, the publication should obtain permission from the university or college.

The advertisements on the web site can take several different forms. First, they can replicate what would be seen in the book format. Unlike the book-format where the advertisements are limited to black and white pictures, the web site can have colorful advertisements. Second, the advertisement can take the form of a banner. The advertisement will display a message and the viewer can "click" on the banner advertisement to go to the company's web site to obtain further information. This is one of the more popular styles of advertising on the Internet. Advertising on the Internet is also more flexible because the advertiser can change the advertisement at any time.

Finally, law reviews and legal journals can obtain an exclusive sponsor for the publication. This will cost the sponsor more than a typical advertisement, for example, approximately $\$ 5,000$ to $\$ 10,000$ per year. However, the sponsor would receive exclusive advertisement rights with the publication. The sponsor would be able to advertise in the book format, and the web site could feature a big spread announcing that the company is the exclusive sponsor of the publication. The sponsor could also have banner advertisements on the web site with click through capabilities. The company 
could further advertise in the publication's offices. Ultimately, the publication benefits because it would only have to deal with one advertiser.

Regardless of how law reviews and legal journals advertise, advertising is much easier to maintain on the business end of the publication as compared to a large subscriber database. The publication will only have to deal with 20 or 30 companies instead of hundreds if not thousands of subscribers. If the law review or legal journal is fortunate to land an exclusive sponsor, then this will make the administrative work even easier.

The final way law reviews and legal journals can generate yearly revenues is to hold an annual dinner banquet for current members and alumni. For the banquet, the publication can try to get a distinguished speaker, announce its current board members, and announce the incoming board members. In addition to raising money for the publication, an annual banquet is a good way for current members of the publication to interact with former members. Whatever the cost of the banquet ends up being, the publication should charge \$5 more per plate, and let everyone know that a portion of the banquet money is benefiting the law review or legal journal. If the banquet is able to draw an average of 400 to 500 alumni and guests per year, then the publication can generate another $\$ 2,000$ to $\$ 2,500$ per year.

The publication can also obtain a sponsor for the banquet. For example, if the publication can get a law firm or other local company to sponsor the banquet for $\$ 2,000$, then the current student members of the publication can attend the banquet for free or at least at a reduced cost. However, the student member's guests would still have to pay. The sponsor would be able to put its company logo on the invitations and on the placement cards at the banquet. Moreover, the sponsor would receive a full-page advertisement spread in the program for the banquet. Finally, the sponsor would be included on the sign behind the speaking podium. Overall, an annual banquet is a great way to raise money for the publication and a great way for current and former members to network.

Ultimately, if the average publication only prints 200 or so books per issue, and the publication advertises and holds an annual banquet, it is quite possible the publication will cover its costs and make a profit of $\$ 5,000$ to $\$ 7,000$ per year. The profits can be used to upgrade computers, scanners, printers, teleconferencing equipment, and whatever else the publication needs to remain competitive. In addition, the law school will no longer need to provide financial support to the publication, except on an Òas neededó basis. Consequently, unless law reviews and legal journals are assured that the law schools will continue to provide financial assistance to support them, these publications should take active steps to generate yearly revenues.

\section{Conclusion}

Law Reviews and legal journals must be willing to change the ways that they edit and publish their issues in order to survive as viable academic resources in the 21st century. Because law reviews and legal journals have historically been criticized as 
being slow, non-deferential to authors, and inflexible, the student editors of each publication must "step-up" to these challenges and improve the publications. Specifically, the student editors should be required to take editing seminars or read stylistic manuals before they are required to perform edits. Nevertheless, law reviews and legal journals should defer to the authors when editing their manuscripts. Moreover, law reviews and legal journals should select their articles "blindly," thus ensuring that the best legal articles are selected and published.

The Internet and technological advances allow law reviews and legal journals to offer new services and features. These publications can now inexpensively publish online, provide hypertext links within articles, provide color graphics, streaming videos, e-mail and teleconference symposiums, and message boards. Moreover, law reviews and legal journals can now e-mail the authors their edited articles instantly and at no cost to the publication, unlike traditional mail services, which are expensive and take at least a day to get to the authors. Law reviews and legal journals can now publish their issues on the Internet for a fraction of what it costs to publish in the book format.

Finally, if law reviews and legal journals begin to advertise and generate revenues by means other than by subscriptions, then these publications will be able to operate without the financial assistance of the law schools. As a result, this will allow the law schools to allocate the money to other areas of need. Furthermore, if the publications can actually make money every year, they can use this surplus to buy new equipment so that they stay up to date with rapidly changing technological advances. Ultimately, law reviews and legal journals must make changes and embrace technology if they are going to survive.

[FN1] Richard S. Harnsberger, Reflections About Law Reviews and American Legal Scholarship, 76 NEB. L. REV. 681, 683 (1997) (explaining that the Harvard Law Review was first published in 1887).

[FN2] See Fred Rodell, Goodbye to Law Reviews, 23 VA. L. REV. 38, 38 (1936); Arthur D. Austin, The "Custom of Vetting" as a Substitute for Peer Review, 32 ARIZ. L. REV. 1, 4 (1990) ("The use of student edited journals as the main outlet for legal writing is an embarrassing situation deserving the smirks of disdain it gets from colleagues in the sciences and humanities.”); James Lindgren, An Author's Manifesto, 61 U. CHI. L. REV. 527, 527 (1994) (“Our scholarly journals are in the hands of incompetents.”); Nathan H. Saunders, note, Student-Edited Law Reviews: Reflections and Responses of an Inmate, 49 DUKE L. J. 1663 (2000) (discussing some of the critics of Law Reviews); Roger C. Cramton, "The Most Remarkable Institution": The American Law Review, 36 J. LEGAL EDUC. 1 (1986) (criticizing that consultation between student editors and faculty has declined, and students do not have a sufficient background to recognize the merit of submissions); Bernard J. Hibbitts, Last Writes? Re-Assessing the Law Review in the Age of Cyberspace, 30 AKRON L. REV. 175 (1996). 
[FN3] Wendy J. Gordon, Counter-Manifesto: Student-Edited Reviews and the Intellectual Properties of Scholarship, 61 U. CHI. L. REV. 541, 541 (1994) (agreeing with James Lindgren that authors' names and affiliations should be physically removed from articles before the articles selection begins).

[FN4] Before students begin editing, every law review and legal journal should require the student members to read at least one or two editing manuals. See Wendy J. Gordon, Counter-Manifesto: Student-Edited Reviews and the Intellectual Properties of Scholarship, 61 U. CHI. L. REV. 541, 541-42 (1994). The student editors should even be required to sit through a couple of seminars on the art of editing. Nathan H. Saunders, note, Student-Edited Law Reviews: Reflections and Responses of an Inmate, 49 DuKE L.J. 1663,1684 (2000).

[FN5] James W. Harper, Why Student-Run Law Reviews?, 82 MinN. L. Rev. 1261, 1275 (1998). Mr. Harper also provides an overview of all of the benefits that Law Reviews provide. Id. at 1272-82.

[FN6] Id. at 1275.

[FN7] Telephone Survey of Five Law Reviews: University of Pittsburgh Law Review, Columbia Law Review, Connecticut Law Review, Cornell Law Review, and Georgetown Law Journal (February 20, 2001).

[FN8] John T. Noonan, Jr., Special Issue: Law Review Conference: Law Reviews, 47 StAN. L. Rev. 1117, 1136 (1995).

[FN9] Telephone Survey of Five Law Reviews: University of Pittsburgh Law Review, Columbia Law Review, Connecticut Law Review, Cornell Law Review, and Georgetown Law Journal (February 20, 2001).

[FN10] Id.

[FN11] Id.

[FN12] Id.

[FN13] Id. Most of the law reviews and legal journals surveyed performed anywhere from four to six separate edits on an author's articles. Id.

[FN14] Telephone Survey of Five Law Reviews: University of Pittsburgh Law Review, Columbia Law Review, Connecticut Law Review, Cornell Law Review, and Georgetown Law Journal (February 20, 2001).

[FN15] Id.

[FN16] Id. 
[FN17] Id.

[FN18] Id.

[FN19] LEXIS and Westlaw are electronic databases that contain numerous legal resources such as cases, statutes, legislative history, law reviews and other legal journals, public records, treatises, and many other legal resources. These databases charge practitioners a fee to use the resources. However, law students are given unlimited access to certain legal resources in both LEXIS and Westlaw.

[FN20] James W. Harper, Why Student-Run Law Reviews?, 82 MinN. L. ReV. 1261, 1276-77 (1998).

[FN21] See Bernard J. Hibbitts, Last Writes? Re-Assessing the Law Review in the Age of Cyberspace, 71 N.Y.U. L. REV. 615, 643-644 (1996).

[FN22] Richard S. Harnsberger, Reflections about Law Reviews and American Legal Scholarship, 76 NeB. L. Rev. 681, 693 (1998) (explaining critics' accusations of student inexperience); see also James Lindgren, An Author's Manifesto, 61 U. Chi. L. Rev. 527 (1994).

[FN23] See James Lindgren, An Author’s Manifesto, 61 U. Chi. L. Rev. 527, 527 (1994) ("Our scholarly journals are in the hands of incompetents.").

[FN24] Howard A. Denemark, The Death of Law Reviews has been Predicted: What Might be Lost When the Last Law Review Shuts Down?, 27 Seton HaLl L. Rev. 1, 5 (1996)(stating that an advantage of the electronic publishing is its ability to reach a larger and more targeted audience, which can even be in remote geographic locations).

[FN25] See generally Bernard J. Hibbitts, Last Writes? Re-Assessing the Law Review in the Age of Cyberspace, 71 N.Y.U. L. REV. 615 (1996).

[FN26] Id. At 615-616. For an example of a self-published legal article by a law professor, see Robert M. Lawless, The Relationship Between NonBusiness Bankruptcy Filings and Various Basic Measures of Consumer Debt, $<$ http://www.law.missouri.edu/lawless/bus_bkr/filings.htm>, Version 1.01 (Last Updated July 18, 2001).

[FN27] Interview with Professor Bernard J. Hibbitts, Professor at the University of Pittsburgh School of Law (October 18, 2000).

[FN28] Id.

[FN29] Id. 
[FN30] Id.

[FN31] Id.

[FN32] Id.

[FN33] Interview with Professor Bernard J. Hibbitts, Professor at the University of Pittsburgh School of Law (October 18, 2000).

[FN34] Id.

[FN35] Interview with Professor Bernard J. Hibbitts, Professor at the University of Pittsburgh School of Law (October 18, 2000); see also Howard A. Denemark, The Death of Law Reviews has been Predicted: What Might be Lost When the Last Law Review Shuts Down?, 27 SETON Hall L. Rev. 1, 5 (1996)(publishing online allows publications to provide information at low cost).

[FN36] Interview with Professor Bernard J. Hibbitts, Professor at the University of Pittsburgh School of Law (October 18, 2000).

[FN37] Id.

[FN38] Interview with Professor Bernard J. Hibbitts, Professor at the University of Pittsburgh School of Law (October 18, 2000).

[FN39] Id.

[FN40] Id.

[FN41] Id.

[FN42] Id.

[FN43] Napster allows users to exchange MP3 files stored on their own computer harddrives directly, without payment or formerly without payment, and it boasts that it "takes the frustration out of locating servers with MP3 files." A \& M Records, Inc. v. Napster, 2000 WL 573136, *1 (N.D. Cal. May 12, 2000).

According to Napster, when a user clicks on the name of a desired MP3 file, the Napster server routes this information to the request to the host user's browser. The host user's browser responds that it either can or cannot supply the file. If the host can supply the file, the Napster server communicates the host's address and routing information to the requesting user's browser, allowing the requesting user to make a connection with the host and receive the desired MP3 file.

Id. at $* 2$. 
[FN44] Interview with Professor Bernard J. Hibbitts, Professor at the University of Pittsburgh School of Law (October 18, 2000).

[FN45] Howard A. Denemark, The Death of Law Reviews has been Predicted: What Might be Lost When the Last Law Review Shuts Down?, 27 Seton Hall L. Rev. 1, 21 (1996) (arguing that students are the ultimate generalists).

[FN46] James W. Harper, Why Student-Run Law Reviews?, 82 MinN. L. Rev. 1261, 1283 (1998) (stating that when selecting articles, students are at their strength as to keeping the law understandable).

[FN47] Peer-review is also an important factor for faculty becoming tenured.

[FN48] In fact, Professor Hibbitts suggests this is one way that "self-publishing" can be validated. Interview with Professor Bernard J. Hibbitts, Professor at the University of Pittsburgh School of Law (October 18, 2000). He suggests that professors rate each other based on the article published online. Id. Any sort of uniform rating scheme could be devised to make matters simpler. Id.

[FN49] Id.

[FN50] See Phil Nichols, Note, A Student Defense of Student Edited Journals: In Response to Professor Roger Cramton, 1987 DuKE L.J. 1122, 1136 (asking where faculty-run publications are going to find student staff members without immediate rewards to entice students when they might have longer term benefits from clerkships and/ or jobs with law firms).

[FN51] Id.

[FN52] Wendy J. Gordon, Counter-Manifesto: Student-Edited Reviews and the Intellectual Properties of Scholarship, 61 U. CHI. L. REV. 541, 541 (1994) (agreeing with James Lindgren, An Author's Manifesto, 61 U. CHI. L. ReV. 527 (1994), that the names and affiliations should be physically removed from articles before selection begins as a partial prophylactic against good articles being ignored).

[FN53] Telephone Survey of Five Law Reviews: University of Pittsburgh Law Review, Columbia Law Review, Connecticut Law Review, Cornell Law Review, and Georgetown Law Journal (February 20, 2001).

[FN54] Bernard J. Hibbitts, Last Writes? Re-Assessing the Law Review in the Age of Cyberspace, 71 N.Y.U. L. REV. 615, 667-683, 684-688 (1996) (arguing that legal scholars might take full advantage of new computer technology by publishing their own scholarship on the World Wide Web.).

[FN55] James Lindgren, An Author's Manifesto, 61 U. CHI. L. Rev. 527, 529-530 (1994). 
[FN56] Howard A. Denemark, The Death of Law Reviews has been Predicted: What Might be Lost When the Last Law Review Shuts Down?, 27 Seton HaLl L. Rev. 1, 5 (1996).

[FN57] Id. at 4.

[FN58] A publication would want to continue publishing a couple hundred books for those "die-hard" subscribers that want to continue receiving the publication in book format, and for archival purposes. Also, the student editors usually like to keep a copy of the issues that they worked on during their time on the law review or legal journal.

[FN59] Professor Hibbitts suggests that these are some of the advantages of "selfpublishing," but he also recognizes that these technological features can be implemented by law reviews and legal journals if they are willing to change. Interview with Professor Bernard J. Hibbitts, Professor at the University of Pittsburgh School of Law (October 18, 2000).

[60] Professor Hibbitts suggests this for Òself-publishing,ó but this too can be implemented by legal publications. Interview with Professor Bernard J. Hibbitts, Professor at the University of Pittsburgh School of Law (October 18, 2000).

[FN61] Interview with Professor Bernard J. Hibbitts, Professor at the University of Pittsburgh School of Law (October 18, 2000).

[FN62] See, e.g., LAW LiBR. J., No. 3 (Summer 2000).

[FN63] Interview with Marc Silverman, Reference Librarian of the University of Pittsburgh School of Law in Pittsburgh, PA (October 25, 2000).

[FN64] Howard A. Denemark, The Death of Law Reviews has been Predicted: What Might be Lost When the Last Law Review Shuts Down?, 27 Seton Hall L. Rev. 1, 5 (1996).

[FN65] See supra Text Part IIB.

[FN66] Again, this is assuming the average legal publication only prints four issues per year. If the publication prints more or less issues, the cost for a subscription should vary accordingly.

[FN67] This is based on the assumption that all of the subscribers pay on time. Also, this does not take into account any single issues that may be sold throughout the year.

[FN68] The University of Pittsburgh Law Review has begun to advertise in its Law Review (e.g., 62 U. PITT L. R. 1 (2000)). The Law Review has used the advertising to supplement its budget and to ensure that its issues are printed and shipped on time. 
Moreover, the Law Review is able to use the revenues from advertising to buy new computer equipment so that the Law Review can keep the whole editing process in-house. 